\title{
Low temperature conditioning treatments reduce external chilling injury of 'Hass' avocados
}

\author{
Allan B. Woolf*, Katy A. Cox, Anne White, Ian B. Ferguson \\ The Horticulture and Food Research Institute of New Zealand, Private Bag 92 169, Auckland, New Zealand
}

Received 17 January 2002; accepted 25 August 2002

\begin{abstract}
Storage of avocado fruit is limited by the development of skin damage (external chilling injury) when fruit are stored at temperatures of less than about $3{ }^{\circ} \mathrm{C}$. The potential for low temperature conditioning to reduce external damage of 'Hass' avocados was examined. Avocados harvested in early summer were conditioned at temperatures of 4, 6, 8, 10, 12 and $15{ }^{\circ} \mathrm{C}$ for a period of $0,1,2,3,4$ or 5 days before 3 weeks storage at $0{ }^{\circ} \mathrm{C}$. Three days after removal from coolstore, external damage was rated, and internal quality assessed after ripening at $15{ }^{\circ} \mathrm{C}$. The experiment was repeated in late summer, but fruit were stored for 4 weeks at $0{ }^{\circ} \mathrm{C}$, and only external damage was measured. Control fruit stored at $0{ }^{\circ} \mathrm{C}$ for either 3 or 4 weeks exhibited severe external damage, manifested as blackening and pitting over almost the whole fruit surface. Conditioning temperatures of $4-10{ }^{\circ} \mathrm{C}$ reduced skin damage. The optimum temperature/time combinations were 6 or $8{ }^{\circ} \mathrm{C}$ for $3-5$ days prior to $0{ }^{\circ} \mathrm{C}$ storage. Ripe-fruit quality was also highest in these treatments. Weight loss, ethylene and $\mathrm{CO}_{2}$ production were not associated with the reduction in external damage, and the response observed is therefore likely to be due to a low temperature, rather than a ripening response.
\end{abstract}

(C) 2002 Elsevier Science B.V. All rights reserved.

Keywords: Persea americana (Mill.); Ethylene; Respiration; Weight loss; Fruit firmness

\section{Introduction}

A major limitation in the storage of 'Hass' avocados is the development of external chilling injury at low temperatures. This occurs at temperatures of about $3{ }^{\circ} \mathrm{C}$ or less, and is expressed as skin blackening and pitting. The damage is first

* Corresponding author. Tel.: +64-815-4200; fax: +64-8154202

E-mail address: awoolf@hortresearch.co.nz (A.B. Woolf). seen in inner cell layers of the exocarp, then moves to the outer layers of the skin (Woolf, 1997). External chilling injury is highly correlated with increased electrolyte leakage of skin tissue (Woolf, 1997; Woolf et al., 2000).

External chilling injury in avocado fruit can be reduced by a number of postharvest techniques, including anaerobic shock treatments (Pesis et al., 1994), and hot air and water treatments (Sanxter et al., 1994; Woolf et al., 1995; Florissen et al., 1996; Woolf, 1997). Although these treatments can effectively reduce chilling injury after commercial 
applications such as low temperature disinfestation against fruit fly (Hofman et al., 2002a), incomplete elimination of external chilling injury, overall ripe-fruit quality and packhouse logistics may make these treatments difficult to implement commercially.

An alternative technique for increasing tolerance to low or 'chilling' temperatures is low temperature conditioning. This involves holding cold-sensitive tissue at temperatures just above those at which injury occurs to induce tolerance to these normally damaging low temperatures. The concept is similar to that used in acquired thermotolerance where treating fruit or other tissues with permissive (non-damaging) high temperatures induces tolerance to higher, normally lethal temperatures. Such tolerance can be acquired in avocado fruit (Woolf and Lay-Yee, 1997).

Many studies have demonstrated that low temperature conditioning of fruit and seedlings can alleviate chilling injury symptoms (Wang, 1993). The crucial factors appear to be the temperature differential between conditioning and storage temperature, and duration of the conditioning treatment. Typical low temperature conditioning treatments effective in reducing chilling injury involve holding fruit such as zucchini for 2 days at 15 or $10{ }^{\circ} \mathrm{C}$ before storage at 5 and $2.5{ }^{\circ} \mathrm{C}$, respectively (Kramer and Wang, 1989a,b; Buta and Wang, 1993). Low temperature conditioning of very chilling sensitive fruits such as papaya at $12.5{ }^{\circ} \mathrm{C}$ for 4 days reduces chilling injury at $2{ }^{\circ} \mathrm{C}$ (Chen and Paull, 1986). Effective durations for low temperature conditioning vary; treatments for seedlings can be as short as 24 or 48 h (Wheaton and Morris, 1967; Lange and Cameron, 1997). Longer conditioning treatments were more successful in two grapefruit cultivars, where fruit conditioned for 7 days had significantly less chilling injury after storage at $1{ }^{\circ} \mathrm{C}$ for 21 days (Hatton and Cubbedge, 1982). In sweet peppers, McColloch (1962) found that exposure to $10{ }^{\circ} \mathrm{C}$ for 5 or 10 days inhibited chilling injury expression at $0{ }^{\circ} \mathrm{C}$.

The South African avocado industry routinely adopts a 'step-down' temperature regime during transport whereby fruit are held at progressively lower temperatures during shipping to Europe
(Vorster et al., 1987). Temperatures typically decrease by $1-2{ }^{\circ} \mathrm{C}$ each week of storage, and the final temperature is not below $3.5{ }^{\circ} \mathrm{C}$. This regime is tailored to cultivar, production region, orchard temperatures, and fruit maturity (Eksteen and Bester, 1987). This practice provides evidence that low temperature conditioning may be a way of reducing external chilling injury in avocado fruit. However, these regimes are relatively longterm, and the potential for chilling injury reduction at very low temperatures using short conditioning times does not appear to have been examined.

With these conditioning practices and results in mind, and with the need to extend storage life of avocado fruit without chilling injury, we have examined short duration low temperature conditioning treatments and their effect on external damage and ripe-fruit quality of 'Hass' avocado fruit stored at $0{ }^{\circ} \mathrm{C}$ for 3 or 4 weeks.

\section{Materials and methods}

\subsection{Fruit}

'Hass' (Persea americana Mill.) avocados (190$220 \mathrm{~g})$ were harvested in mid-November, 1998 (early summer, about the middle of the commercial harvest period, average dry matter $=33.7 \pm$ $0.2 \%$ ), from a commercial orchard in Whangarei, New Zealand. Because chilling sensitivity changes with fruit maturity/time in the season, the experiment was repeated in February with late summer fruit (late maturity, dry matter $=37.6 \pm 0.5 \%$ ) from the same orchard, to verify the conditioning effect on external chilling injury. Harvest temperatures ranged from 22 to $24{ }^{\circ} \mathrm{C}$. Fruit were held overnight at ambient packhouse temperatures (minimum of $12-16{ }^{\circ} \mathrm{C}$ ), then graded and packed on the following day. Fruit were further graded for appearance (freedom from blemishes, damage and sunburn), and randomised into treatments. Handling, treatment and storage of fruit was carried out using commercial single layer cardboard trays. 


\subsection{Experiments}

Two conditioning experiments were carried out with fruit temperatures of $4,6,8,10,12$ or $15{ }^{\circ} \mathrm{C}$ for a period of $0,1,2,3,4$ or 5 days before placement into cool storage at $0{ }^{\circ} \mathrm{C}$ for 3 weeks (November experiment; early summer; Table 1) or 4 weeks (February experiment; late summer; Table 1). External quality was assessed three days after removal from storage (when external chilling injury tends to be expressed fully). For the November experiment, fruit were ripened at $15{ }^{\circ} \mathrm{C}$ and fruit quality assessed. A temperature of $15{ }^{\circ} \mathrm{C}$ was employed to reduce disease incidence (Hopkirk et al., 1994). Fruit temperatures were monitored throughout treatment using Squirrel Data Loggers (Model 1206; Grant, Cambridge, UK) equipped with thermistor temperature probes (CM-UU-V5-1; Grant, Cambridge, UK). Cooling rates $\left(t_{1 / 2}\right)$ were approx. $2.5 \mathrm{~h}$. Each treatment contained three replicates, each of 13 fruit.

\subsection{Fruit measurements}

\subsubsection{Fruit maturity}

Dry matter content at harvest was determined on three samples of three fruit. Each fruit was cut into quarters, and one quarter peeled, the seed coat removed, and the flesh grated in a food processor. Dry matter was determined by drying each $20 \mathrm{~g}$ sample for $24 \mathrm{~h}$ at $60{ }^{\circ} \mathrm{C}$.

\subsubsection{Firmness assessments}

Fruit firmness was measured on a sub-sample of ten fruit using a digital firmometer (Ross Anderson Engineering, Tauranga, NZ; White et al., 1999). Firmometer values were determined in the November experiment immediately after the conditioning treatment, and again after overnight rewarming following removal from $0{ }^{\circ} \mathrm{C}$. The firmometer value derived $(0-110)$ is the displacement $(\mathrm{mm})$ of a hemispherical probe multiplied by 10 . Thus, as fruit soften, firmometer values increase.

\subsubsection{Fruit quality; external damage}

The level of external damage (manifested as blackening of the skin of lenticels, or irregular patches on the skin) was assessed after 3 and 4 weeks of storage at $0{ }^{\circ} \mathrm{C}$ (November and February experiments, respectively). Fruit were rated on a relative scale from 0 to $3(0=$ no occurrence, $0.5=<10 \%, 1.0=>10 \leq 20 \%, 1.5=>20 \leq$ $50 \%, \quad 2.0=>50 \leq 75 \%, \quad 2.5=>75 \leq 90 \%$, $3.0=>90 \%$ of the fruit surface damaged). External chilling injury was evaluated at removal from storage, and again after fruit had been kept at $15{ }^{\circ} \mathrm{C}$ for 3 days.

\subsubsection{Ripe-fruit quality}

A full assessment of ripe-fruit quality was only carried out on the November harvest. Fruit were assessed for quality once ripe (average firmometer value of $>100$ using a $300 \mathrm{~g}$ weight or 80 using a $200 \mathrm{~g}$ weight; White et al., 1999). Ripeness was

Table 1

Conditioning and control treatment combinations $(\mathrm{N}=$ November, early summer; $\mathrm{F}=$ February, late summer $)$

\begin{tabular}{|c|c|c|c|c|c|c|}
\hline \multirow[t]{2}{*}{ Temperature $\left({ }^{\circ} \mathrm{C}\right)$} & \multirow{2}{*}{$\frac{\text { Control }}{0 \text { days }}$} & \multicolumn{5}{|c|}{ Time in conditioning treatment (days) } \\
\hline & & 1 days & 2 days & 3 days & 4 days & 5 days \\
\hline 15 & $\mathrm{C}^{\mathrm{ns}}$ & $\mathrm{N}, \mathrm{F}$ & & $\mathrm{N}, \mathrm{F}$ & & $\mathrm{N}, \mathrm{F}$ \\
\hline 12 & & $\mathrm{~N}, \mathrm{~F}$ & & $\mathrm{~N}, \mathrm{~F}$ & & $\mathrm{~N}, \mathrm{~F}$ \\
\hline 10 & & $\mathrm{~N}, \mathrm{~F}$ & $\mathrm{~F}$ & $\mathrm{~N}, \mathrm{~F}$ & $\mathrm{~N}$ & $\mathrm{~N}, \mathrm{~F}$ \\
\hline 8 & & $\mathrm{~N}, \mathrm{~F}$ & $\mathrm{~F}$ & $\mathrm{~N}, \mathrm{~F}$ & & $\mathrm{~N}, \mathrm{~F}$ \\
\hline 6 & & $\mathrm{~N}, \mathrm{~F}$ & $\mathrm{~N}, \mathrm{~F}$ & $\mathrm{~N}, \mathrm{~F}$ & $\mathrm{~N}, \mathrm{~F}$ & $\mathrm{~N}, \mathrm{~F}$ \\
\hline 4 & & $\mathrm{~N}, \mathrm{~F}$ & $\mathrm{~F}$ & $\mathrm{~N}, \mathrm{~F}$ & & $\mathrm{~N}, \mathrm{~F}$ \\
\hline 0 & $\mathrm{C}^{\mathrm{s}}$ & & & & & \\
\hline
\end{tabular}

$\mathrm{C}^{\mathrm{ns}}$, non-stored control; $\mathrm{C}^{\mathrm{s}}$, stored control. Fruit were then stored at $0{ }^{\circ} \mathrm{C}$ for 3 weeks (November experiment), or 4 weeks (February experiment). 
determined daily by gentle hand squeezing by one trained assessor. The number of days taken to ripen was recorded (days to ripen; DTR). Once ripe, fruit quality was determined by cutting fruit into quarters longitudinally, and the following factors evaluated: hard skin (hardness or brittleness of the skin determined when cutting and peeling back the skin), uneven ripening (uneven flesh softening such that flesh tissue adhered to the seed when fruit was cut in half), tissue breakdown (breakdown of emerald green flesh adjacent to the skin such that tissue adhered to the skin when peeled), body rots (rots entering through the skin), stem end rots (rots entering only through the fruit peduncle), vascular browning (browning of the vascular strands running longitudinally through the fruit tissue), flesh browning (browning of the fruit tissue not due to disease or vascular browning), and seed cavity browning (browning of the fruit tissue in the seed cavity which is not due to disease or flesh browning). Each factor was rated on a scale from 0 to 3 in 0.5 intervals, where $0=$ no occurrence; $1=$ slight; $2=$ a level at which the consumer would possibly reject the fruit; $3=$ severe (Hopkirk et al., 1994). The proportion of sound fruit was defined as the percentage of fruit with no unacceptable damage levels (rating $<2$ ) with each fruit rated individually as sound or not at the time of assessment.

\subsubsection{Ethylene production and respiration rate}

In the November experiment, ethylene production and respiration rates were measured on days $1,2,3$, and 5 while fruit were held at conditioning temperatures of 6,12 and $15{ }^{\circ} \mathrm{C}$. The non-stored control fruit $\left(15{ }^{\circ} \mathrm{C}\right)$ were measured daily until the climacteric maximum was reached (approximately 14 days). In the February experiment, ethylene production and respiration rates were measured on the non-stored control treatment only, until day 12. Ethylene and $\mathrm{CO}_{2}$ production was measured by sealing ten fruit per treatment individually in 11 containers for $1 \mathrm{~h}$, and ethylene and $\mathrm{CO}_{2}$ concentrations measured by conventional gas chromatography.

\subsection{Statistics}

The design had two factors, conditioning temperature $\left(15-4{ }^{\circ} \mathrm{C}\right)$, and conditioning duration (0-5 days). The data were analysed as a randomised block design, cubic orthogonal polynomial contrasts, and their interactions were fitted, in both factors. Data are presented as average severity rating, or as percent incidence (percentage of fruit with attribute rated as present; i.e. severity rating $>0$ ). Percent incidence data were transformed using angular transformation (arc$\sin (\operatorname{sqrt}(\mathrm{X})))$, and transformed means are presented.

\section{Results}

\subsection{External damage after storage}

When fruit were removed from $0{ }^{\circ} \mathrm{C}$, low temperature external injury was evident as discrete blackening of patches of the skin surface. After 3 days at $15{ }^{\circ} \mathrm{C}$, damage levels increased slightly, and only the 3-day data are presented (Fig. 1).

\subsubsection{November experiment}

Control (non-conditioned) fruit held at $0{ }^{\circ} \mathrm{C}$ for 3 weeks had severe levels of external injury (rating of 2, i.e. $50-75 \%$ of the skin surface damaged), while fruit held at $15{ }^{\circ} \mathrm{C}$ continually (non-coolstored control) had no external damage symptoms (Fig. 1A). Lower conditioning temperatures and longer times progressively reduced external damage (Fig. 1A; Table 2). With the exception of 12 or $15{ }^{\circ} \mathrm{C}$ conditioning temperatures, increasing conditioning duration reduced external damage $(P<0.05)$. Low temperature conditioning treatments of 6 or $8{ }^{\circ} \mathrm{C}$ for $3-5$ days reduced external injury to negligible levels. At all the lowest conditioning temperature $\left(4{ }^{\circ} \mathrm{C}\right)$, longer conditioning times were required to reduce external damage.

\subsubsection{February experiment}

The longer storage time used in this experiment ( 4 vs. 3 weeks at $0{ }^{\circ} \mathrm{C}$ ), resulted in slightly higher external damage ( $\cong 0.5$ increase in rating) (Fig. 


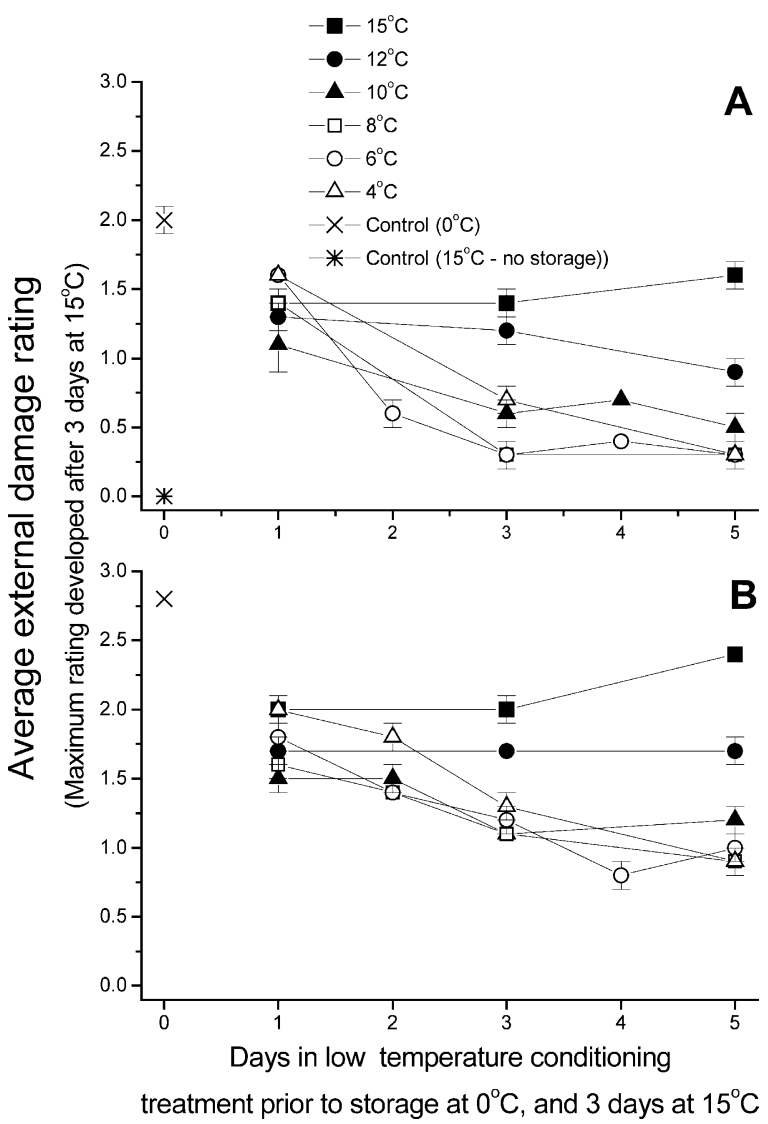

Fig. 1. Effect of low temperature conditioning treatments (4$15{ }^{\circ} \mathrm{C}$ for $0-5$ days) on external damage of 'Hass' avocados once fruit were removed from coolstore (A: November experiment, 3 weeks; or B: February experiment, 4 weeks at $0{ }^{\circ} \mathrm{C}$ ) and rated after 3 days at $15{ }^{\circ} \mathrm{C}$ (rating scale; $0=$ no occurrence, $3=$ damage of $>90 \%$ of the surface). Each point represents the average of three replicates of 13 fruit. Vertical bars $=$ S.E.M.

1B). The difference in external damage between non-conditioned fruit and the best treatments was similar ( $\cong 1.75 \mathrm{U})$. Similarly, the external damage pattern in response to the conditioning treatments was almost identical to that in the November experiment, except that the $10{ }^{\circ} \mathrm{C}$ treatment appeared to result in a slightly larger reduction in damage (compare 3 and 4 days conditioning at $10{ }^{\circ} \mathrm{C}$ ). Conditioning at $4{ }^{\circ} \mathrm{C}$ was slightly less effective at 2 days, but was as effective as $6{ }^{\circ} \mathrm{C}$ after 5 days.

In both experiments, conditioning temperatures of 6 or $8{ }^{\circ} \mathrm{C}$ resulted in the most rapid decrease of, and lowest overall, external damage, while temperatures of 4 or $10{ }^{\circ} \mathrm{C}$ were generally slightly less effective, and 12 and $15{ }^{\circ} \mathrm{C}$ the least effective.

\subsection{Days to ripen (DTR) and fruit firmness}

Fruit held under lower conditioning temperatures had longer DTR (Table 2). Fruit held at $4{ }^{\circ} \mathrm{C}$ took approx. 1.5-2 days longer to ripen than fruit held at $15{ }^{\circ} \mathrm{C}$, and increased conditioning duration tended to increase the DTR (approx. 1 day; $P<0.05$ ). Fruit firmness after storage showed a similar, but inverse pattern to that of DTR, with fruit conditioned at lower temperatures remaining firmer longer (data not shown).

\subsection{Internal fruit quality}

\subsubsection{Sound fruit}

Fruit ripened without storage were of high quality ( $87 \%$ sound), while storing fruit at $0{ }^{\circ} \mathrm{C}$ for 3 weeks without conditioning led to a decrease in quality ( $57 \%$ sound, Table 2$)$. Conditioning treatments of 10 or $12{ }^{\circ} \mathrm{C}$ with longer conditioning periods generally resulted in lower overall quality, while at 6 or $8{ }^{\circ} \mathrm{C}$, conditioning durations of 3-5 days resulted in the highest fruit quality (Table 2).

\subsubsection{Stem end rots}

Incidence of stem end rots was moderate (approx. 20-30\%) in a large number of treatments, and was $21 \%$ for the non-coolstored, non-conditioned fruit (Table 2). Conditioning temperature and duration effects on stem end rots were significant $(P<0.05)$, as was the interaction $(P<0.001)$. Stem end rot incidence was lowest in fruit conditioned at $8{ }^{\circ} \mathrm{C}$ for 1 and 3 days.

\subsubsection{Body rots}

The incidence of body rots was lowest in control, non-stored fruit $(21 \%)$ and increased to $49 \%$ in coolstored control fruit (Table 2). The incidence of body rots was moderate to high in all conditioned treatments, with $79 \%$ of fruit conditioned at $15{ }^{\circ} \mathrm{C}$ for 5 days having some level of body rot. Conditioning temperature and duration effects were significant at the $P<0.05$ level with 
Table 2

November experiment (early summer). Quality of 'Hass' avocado fruit following low temperature conditioning treatments $\left(4-15{ }^{\circ} \mathrm{C}\right.$ for $1-5$ days), storage at $0{ }^{\circ} \mathrm{C}$ for 3 weeks, and then ripening at $15{ }^{\circ} \mathrm{C}$. External damage was rated 3 days after removal from coolstore. Days to ripen (DTR) defined as time to reach an average firmometer value of 100 (White et al., 1999). 'Percent sound' is defined as the proportion of fruit showing no unacceptable quality factors. All other factors were rated on a scale of 0 $3(0=$ none to $3=$ severe) and data are presented as severity (average severity rating) or incidence (percent fruit with any occurrence of the disorder; ratings $>0$ ) Incidence data are presented in the transformed form. Controls: fruit either ripened directly at $15{ }^{\circ} \mathrm{C}$ (no storage), or ripened at $15{ }^{\circ} \mathrm{C}$ following 3 weeks at $0{ }^{\circ} \mathrm{C}$ with no conditioning.

\begin{tabular}{|c|c|c|c|c|c|c|c|c|}
\hline \multicolumn{2}{|l|}{ Conditioning treatment } & \multirow{2}{*}{$\begin{array}{l}\text { External damage } \\
\text { Severity }\end{array}$} & \multirow{2}{*}{$\begin{array}{l}\text { DTR (days) } \\
\text { Mean }\end{array}$} & \multirow{2}{*}{$\begin{array}{l}\text { Percent sound (\%) } \\
\text { Incidence }\end{array}$} & \multirow[t]{2}{*}{ Stem-end rots $(\%)$} & \multirow[t]{2}{*}{ Body rots $(\%)$} & \multirow[t]{2}{*}{ Tissue breakdown (\%) } & \multirow[t]{2}{*}{ Hard skin (\%) } \\
\hline Duration (days) & Temp. $\left({ }^{\circ} \mathrm{C}\right)$ & & & & & & & \\
\hline 1 & 15 & 1.4 & 9.3 & 71.5 & 18.4 & 38.5 & 22.63 & 38.3 \\
\hline 1 & 12 & 1.3 & 9.9 & 70.0 & 20.3 & 44.3 & 22.0 & 41.1 \\
\hline 1 & 10 & 1.1 & 10.0 & 79.2 & 13.1 & 33.2 & 10.7 & 42.5 \\
\hline 1 & 8 & 1.4 & 10.0 & 86.9 & 5.4 & 30.4 & 10.7 & 29.7 \\
\hline 1 & 6 & 1.6 & 11.1 & 58.9 & 20.3 & 35.1 & 24.5 & 36.2 \\
\hline 1 & 4 & 1.6 & 11.3 & 55.7 & 27.7 & 51.7 & 33.6 & 54.9 \\
\hline 2 & 6 & 0.6 & 10.3 & 83.9 & 15.4 & 22.6 & 5.4 & 10.7 \\
\hline 3 & 15 & 1.4 & 10.0 & 48.4 & 32.0 & 55.3 & 25.0 & 47.5 \\
\hline 3 & 12 & 1.2 & 10.8 & 61.7 & 33.2 & 38.3 & 14.9 & 38.2 \\
\hline 3 & 10 & 0.6 & 10.7 & 75 & 20.3 & 39.7 & 0 & 27.3 \\
\hline 3 & 8 & 0.3 & 10.8 & 74.2 & 0 & 32.4 & 0 & 26.6 \\
\hline 3 & 6 & 0.3 & 11.2 & 73 & 29.7 & 27.7 & 5.4 & 26.6 \\
\hline 3 & 4 & 0.7 & 11.9 & 68.3 & 28.2 & 36.5 & 0 & 25.0 \\
\hline 4 & 10 & 0.7 & 10.5 & 63.2 & 23.1 & 34.7 & 5.4 & 30.2 \\
\hline 4 & 6 & 0.4 & 11.8 & 91.5 & 28.5 & 39.7 & 0 & 26.6 \\
\hline 5 & 15 & 1.6 & 10.3 & 20.7 & 65.0 & 79.3 & 39.8 & 71.6 \\
\hline 5 & 12 & 0.9 & 11.0 & 51.3 & 48.8 & 54.9 & 0 & 38.3 \\
\hline 5 & 10 & 0.5 & 10.9 & 63.2 & 31.7 & 48.7 & 0 & 33.6 \\
\hline 5 & 8 & 0.3 & 10.5 & 64.9 & 24.0 & 41.2 & 0 & 27.7 \\
\hline 5 & 6 & 0.3 & 11.6 & 72.2 & 34.5 & 44.2 & 5.4 & 31.9 \\
\hline 5 & 4 & 0.3 & 11.7 & 66.4 & 35.1 & 48.7 & 0 & 26.8 \\
\hline Control $0{ }^{\circ} \mathrm{C}$ & & $2.0 \pm 0.1$ & $10.5 \pm 0.20$ & $57.3 \pm 5.19$ & $33.4 \pm 4.69$ & $48.7 \pm 1.49$ & $39.6 \pm 5.58$ & $56.8 \pm 5.69$ \\
\hline Control $15{ }^{\circ} \mathrm{C}$ & & $0 \pm 0$ & $16.3 \pm 0.27$ & $86.9 \pm 6.84$ & $20.8 \pm 2.33$ & $20.8 \pm 2.33$ & $0 \pm 0$ & $0 \pm 0$ \\
\hline LSD & 0.05 & 0.17 & 1.00 & 17.56 & 16.96 & 14.11 & 13.48 & 15.14 \\
\hline \multicolumn{9}{|l|}{ Significance } \\
\hline \multirow[t]{2}{*}{ Duration } & $\mathrm{L}$ & $* * *$ & * & * & * & * & * & NS \\
\hline & $\mathrm{Q}$ & $* * *$ & NS & NS & NS & * & NS & NS \\
\hline \multirow[t]{3}{*}{ Temperature } & $\mathrm{L}$ & $* * *$ & $*$ & $* * *$ & * & * & $*$ & $* * *$ \\
\hline & Q & $* * *$ & $* * *$ & *** & *** & * & $* * *$ & $* * *$ \\
\hline & $\mathrm{C}$ & $*$ & $*$ & NS & * & NS & NS & NS \\
\hline \multirow[t]{3}{*}{ Duration $\times$ temperature } & $\mathrm{L} \times \mathrm{L}$ & $* * *$ & $* * *$ & $* * *$ & $* * *$ & * & $* * *$ & $* * *$ \\
\hline & $\mathrm{Q} \times \mathrm{L}$ & * & NS & NS & NS & NS & NS & NS \\
\hline & $\mathrm{L} \times \mathrm{Q}$ & $* * *$ & NS & NS & NS & NS & * & NS \\
\hline
\end{tabular}

LSD, least significant difference for the 2-way interaction at $P \leq 0.05 . \mathrm{L}, \mathrm{Q}, \mathrm{C}=$ linear, quadratic, cubic. NS, $*$, **; non significant, significant at the $P \leq 0.05, P \leq$ 0.001 , respectively. 
rots generally decreasing with longer duration, and conditioning temperature below $10{ }^{\circ} \mathrm{C}$.

\subsubsection{Tissue breakdown}

No tissue breakdown was observed in control fruit, but there was a high incidence $(40 \%)$ in coolstored fruit (Table 2). Conditioning reduced tissue breakdown following coolstorage. After 3 days conditioning, tissue breakdown was very low in temperatures of $10{ }^{\circ} \mathrm{C}$ and below. The incidence of tissue breakdown correlated highly with the severity of external damage $\left(r^{2}=0.88, P<\right.$ $0.0001)$.

\subsubsection{Hard skin}

No hard skin was observed in non-coolstored control fruit, but a high incidence $(57 \%)$ was observed in coolstored fruit (Table 2). Conditioning temperatures of $<10{ }^{\circ} \mathrm{C}$ for 3 days or more halved the incidence of hard skin. Decreasing conditioning temperature had the greatest effect $(P<0.0001)$ on reducing the incidence of hard skin.

\subsubsection{Uneven ripening and vascular browning}

Uneven ripening and vascular browning incidence was low ( $<5 \%$ and approx. $10 \%$; respectively), and no significant treatment effects were found (data not shown).

\subsubsection{Ethylene production and respiration rate}

The onset of the ethylene climacteric for nonstored fruit ripened at $15{ }^{\circ} \mathrm{C}$ occurred 5 days after harvest and peaked at day 12 (Fig. 2A). Carbon dioxide production decreased over the first 5 days, then increased, plateauing between 10 and 14 days after harvest (Fig. 2B). During the first 5 days after harvest, no increase in ethylene production could be detected at either 6 or $12{ }^{\circ} \mathrm{C}$ (Fig. 2A) and $\mathrm{CO}_{2}$ levels declined in a similar manner to that of fruit at $15{ }^{\circ} \mathrm{C}$ (Fig. 2B).

\subsubsection{Weight loss}

Weight loss increased during the conditioning treatments and subsequent storage at $0{ }^{\circ} \mathrm{C}$. Over the 5 day conditioning period, weight loss was $0.15,0.21$ and $0.32 \%$ /day (mean S.E.M. \pm 0.014 ) for 6,12 and $15{ }^{\circ} \mathrm{C}$, respectively. Fruit in all treatments lost an average of $1.7 \%$ during the 3 week period at $0{ }^{\circ} \mathrm{C}$.

\section{Discussion}

Low temperature conditioning of avocado fruit is a potentially powerful tool for reducing external chilling injury. Our results show that the extremely high levels of external chilling injury exhibited by control fruit could be greatly reduced by conditioning treatments. The optimum (most consistent) conditioning treatments were $6-8{ }^{\circ} \mathrm{C}$ for $3-5$ days, while 4 and $10{ }^{\circ} \mathrm{C}$ were moderately effective, and 12 and $15{ }^{\circ} \mathrm{C}$ were the least effective. It is unlikely that longer durations at the higher temperatures (e.g. $12-15{ }^{\circ} \mathrm{C}$ ) would lead to further reduction in chilling injury, since external damage did not decrease with increasing conditioning duration at these temperatures. Similar low temperature conditioning effects have been observed in other crops such as papaya (Chen and Paull, 1986) and zucchini (Kramer and Wang, 1989a,b; Buta and Wang, 1993), but the timetemperature relationship has not been as fully explored.

While the greatest conditioning effect was on external damage (Table 2), conditioning also affected a range of disorders associated with ripe fruit quality. For example, the incidence of hard skin and tissue breakdown were also reduced, or even eliminated, by conditioning treatments. Conditioning treatments generally reduced rot incidence. Although rot incidence was relatively high in many treatments, the severity was low such that proportion of unacceptable fruit in optimal conditioning treatments was similar to, or higher than fruit ripened directly at $15{ }^{\circ} \mathrm{C}$.

One of the hypotheses for the conditioning response is that during conditioning, fruit begin to ripen and become less sensitive to chilling temperatures. A reduction in chilling injury with increased ripeness has been observed in fruits such as papaya (Chan, 1988) and avocado (Kosiyachinda and Young, 1976). In the latter case, external injury in 'Fuerte' fruit after about 3 weeks storage at $2{ }^{\circ} \mathrm{C}$ was greater for pre- than for postclimacteric fruit. Our results do not fit a response 

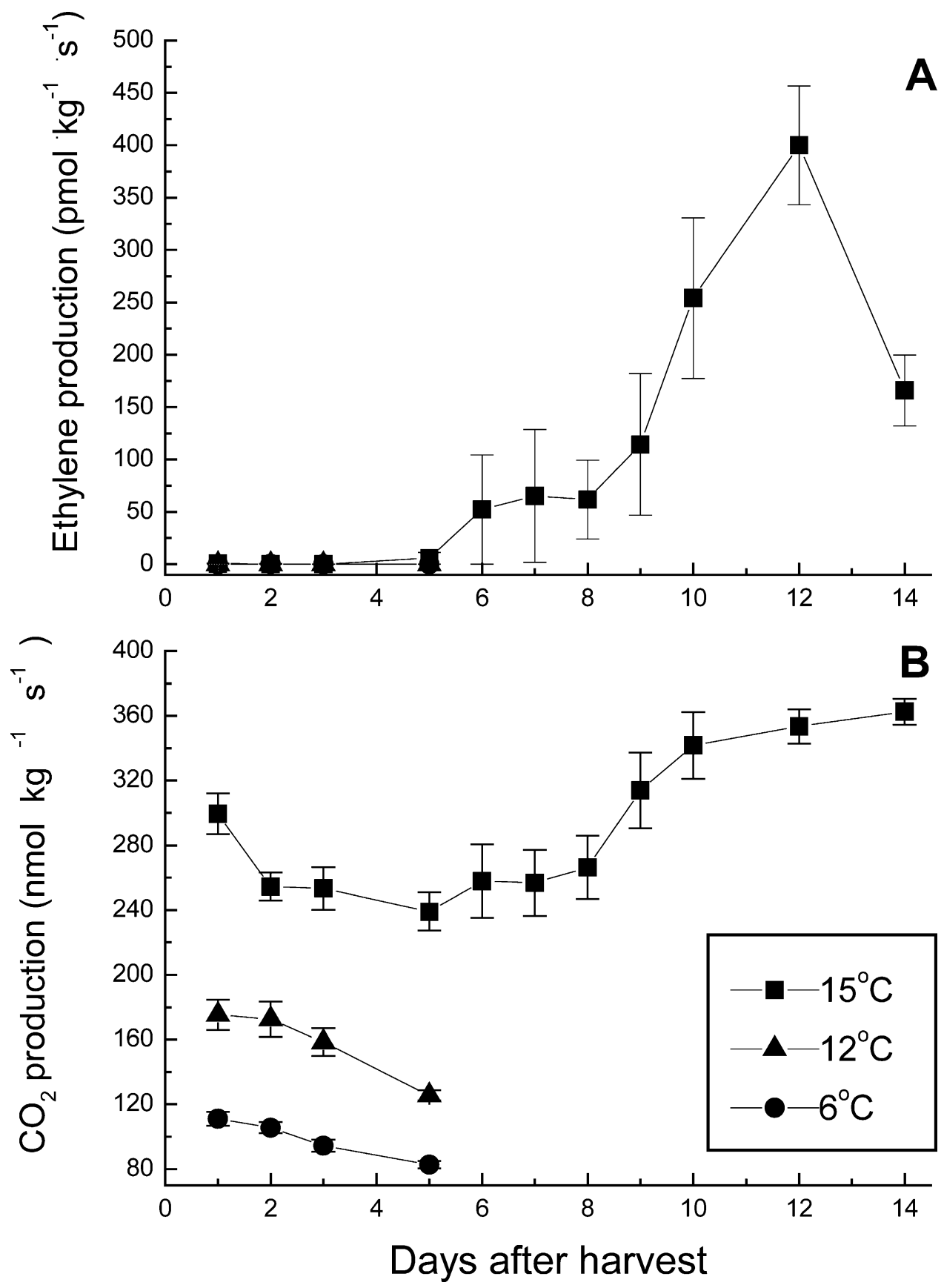

Fig. 2. November experiment (early summer). (A) Average ethylene and (B) carbon dioxide production of 'Hass' avocado fruit held at air temperatures of 6,12 or $15{ }^{\circ} \mathrm{C}$. Each point represents the average of ten fruit. Vertical bars = S.E.M.

based on ripening since lower temperatures (4 or $6{ }^{\circ} \mathrm{C}$ ), which slow fruit ripening (softening), were found to result in less chilling injury than higher temperatures where ripening might be expected to have started. Also, the times examined here were short and the fruit exhibited little or no change in 
respiration and ethylene production or firmness over the conditioning period.

Another hypothesis is that chilling injury in avocado fruit is associated with increased water loss, where coolstored fruit become more sensitive to water loss (Cutting and Wolstenholme, 1992). Reduced water loss in storage has also been associated with reduced incidence of physiological disorders (Bower et al., 1990). Our results do not fit this response since the fruit that had no prior conditioning (hence less weight loss), developed severe external damage.

We suggest that the fruit response observed in this work is most likely due to biochemical or physiological effects. The majority of beneficial conditioning treatments reported in the literature (Wang, 1993), are in the $10-20{ }^{\circ} \mathrm{C}$ range, for protection against storage temperatures of about $6{ }^{\circ} \mathrm{C}$ or less. In many of these cases, the conditioning temperature is not one where we might expect low temperature responses. This is in contrast to our results, where the most beneficial temperatures were 6 and $8{ }^{\circ} \mathrm{C}$ and temperatures above $10{ }^{\circ} \mathrm{C}$ were largely ineffectual. Increased concentrations of polyamines have been significantly associated with $10{ }^{\circ} \mathrm{C}$ conditioning in zucchini squash, and a number of studies have related low temperature protection with enhanced polyamine levels (Kramer and Wang, 1989b; Wang 1993). Relatively high conditioning temperatures have also been shown to reduce chillinginduced degradation of membrane phospholipids, a fundamental symptom of low temperature stress (Wang et al., 1992). Induction of specific protective proteins is another likely low temperature conditioning response. This is well established in acclimation of crop plants to freezing, where specific proteins (such as the COR family) have been associated with protection against freezing damage (Thomashow, 1998). Surprisingly, there has been little research on the biochemical and molecular responses to the temperature differentials that we have used in the chilling response.

One commercial application of this work is in the use of low temperatures $\left(<1{ }^{\circ} \mathrm{C}\right.$ for 16 days) for cold disinfestation of fruit fly. This has been examined by Hofman et al. (2002b) and low temperature conditioning was found to be effective for 'Hass' avocados at both experimental and commercial levels. In addition, packhouse practices (such as holding fruit at intermediate temperatures before final coolstorage) may reduce subsequent chilling sensitivity of 'Hass' avocados. Storage of conditioned fruit at low temperatures may provide longer-term storage.

\section{Acknowledgements}

Thanks to Anne Gunson for statistical analysis, and David Roy of Huanui packhouse, Whangarei for supply of fruit. This work was funded by the Foundation for Research Science and Technology Contract CO6X0007.

\section{References}

Bower, J.P., Cutting, J.G.M., Truter, A.B., 1990. Container atmosphere as influencing some physiological browning mechanisms in stored Fuerte avocado. Acta Hortic. 269, $315-321$.

Buta, J.G., Wang, C.Y., 1993. Early detection of chilling injury with Fourier transform infrared spectroscopy. HortScience $28,1043-1044$.

Chan, H.T., Jr, 1988. Alleviation of chilling injury in papayas. HortScience 23, 868-870.

Chen, N.-M., Paull, R.E., 1986. Development and prevention of chilling injury in papaya fruit. J. Am. Soc. Hort. Sci. 111, $639-643$.

Cutting, J.G.M., Wolstenholme, B.N., 1992. Maturity and water loss effects on avocado (Persea americana Mill.) postharvest physiology in cool environments. J. Hortic. Sci. 67, 569-575.

Eksteen, G.J., Bester, J.M., 1987. Storage and transport of avocados - practical considerations for the South African export situation. S. Afr. Avocado Growers Assoc. Yearbook 10, 157-159.

Florissen, P., Ekman, J.S., Blumenthal, C., McGlasson, W.B., Condroy, J., Holford, P., 1996. The effects of short heattreatments on the induction of chilling injury in avocado fruit (Persea americana Mill.). Postharvest Biol. Technol. 8, $129-141$.

Hatton, T.T., Cubbedge, R.H., 1982. Conditioning Florida grapefruit to reduce chilling injury during low temperature storage. J. Am. Soc. Hort. Sci. 107, 57-60.

Hofman, P.J., Stubbings, B.A., Adkins, M.F., Meiburg, G.F., Woolf, A.B., 2002a. Hot water treatments improve 'Hass' avocado fruit quality after cold disinfestations. Postharvest Biol. Technol. 24, 183-192. 
Hofman, P.J., Stubbings, B.A., Adkins, M.F., Corcoran, R.J., White, A., Woolf, A.B., 2002b. Low temperature conditioning treatments before cold disinfestation improve 'Hass' avocado fruit quality. Postharvest Biol. Technol. In Press.

Hopkirk, G., White, A., Beever, D.J., Forbes, S.K., 1994. Influence of postharvest temperatures and the rate of fruit ripening on internal postharvest rots and disorders of New Zealand 'Hass' avocado fruit. N. Z. J. Crop Hort. Sci. 22, 305-311.

Kosiyachinda, S., Young, R.E., 1976. Chilling sensitivity of avocado fruit at different stages of the respiratory climacteric. J. Am. Soc. Hort. Sci. 101, 665-667.

Kramer, G.F., Wang, C.Y., 1989a. Reduction of chilling injury in zucchini squash by temperature management. HortScience 24, 995-996.

Kramer, G.F., Wang, C.Y., 1989b. Correlation of reduced chilling injury with increased spermine and spermidine levels in zucchini squash. Physiol. Plant. 76, 479-484.

Lange, D.L., Cameron, A.C., 1997. Pre- and postharvest temperature conditioning of greenhouse-grown sweet basil. HortScience 32, 114-116.

McColloch, L.P., 1962. Chilling injury and alternaria rot of bell peppers. U.S. Dept. Agr. Mktg. Res. Rpt. 536, 1-5.

Pesis, E., Marinsky, R., Zauberman, G., Fuchs, Y., 1994. Prestorage low oxygen atmosphere treatment reduces chiling injury symptoms in 'Fuerte' avocado fruit. HortScience $29,1042-1046$.

Sanxter, S.S., Nishijima, K.A., Chan, H., 1994. Heat-treating 'Sharwil' avocado for cold tolerance in cold treatments. HortScience 29, 1166-1168.

Thomashow, M.F., 1998. Role of cold-responsive genes in plant freezing tolerance. Plant Physiol. 118, 1-7.
Vorster, L.L., Toerien, J.C., Bezuidenhout, J.J., 1987. A storage temperature regime for South African export avocados. S. Afr. Avocado Growers Assoc. Yearbook 10, 146-148.

Wang, C.Y., 1993. Approaches to reduce chilling injury of fruits and vegetables. Hort. Rev. 15, 63-95.

Wang, C.Y., Kramer, G.F., Whitaker, B.D., Lusby, W.R., 1992. Temperature preconditioning increases tolerance to chilling injury and alters lipid composition in zucchini squash. J. Plant Physiol. 140, 229-235.

Wheaton, T.A., Morris, L.L., 1967. Modification of chilling sensitivity by temperature conditioning. Proc. Am. Soc. Hort. Sci. 91, 529-533.

White, A., Woolf, A.B., Harker, F.R., Davy, M.W., 1999. Measuring avocado firmness: assessment of various methods. World Avocado Congress IV Proceedings, Uruapan, Mexico, Oct 1999. Revisita Chapingo Ser. Hortic. 5, 389392.

Woolf, A.B., 1997. Reduction of chilling injury in stored 'Hass' avocado fruit by $38{ }^{\circ} \mathrm{C}$ water treatments. HortScience 32, $1247-1251$.

Woolf, A.B., Lay-Yee, M., 1997. Pretreatments at $38{ }^{\circ} \mathrm{C}$ of 'Hass' avocado confer thermotolerance to $50{ }^{\circ} \mathrm{C}$ hot-water treatments. HortScience 32, 705-708.

Woolf, A.B., Watkins, C.B., Bowen, J.H., Lay-Yee, M., Maindonald, J.H., Ferguson, I.B., 1995. Reducing external chilling injury in stored 'Hass' avocados with dry heat treatments. J. Am. Soc. Hort. Sci. 120, 1050-1056.

Woolf, A.B., Wexler, A., Prusky, D., Kobiler, E., Lurie, S., 2000. Direct sunlight influences postharvest temperature responses and ripening of five avocado cultivars. J. Am. Soc. Hort. Sci. 125, 370-376. 